\title{
Flesh flies (Diptera: Sarcophagidae) of sandy and marshy habitats of the Polish Baltic coast
}

\section{Elżbieta Kaczorowska}

\begin{abstract}
Kaczorowska, E. 2009: Flesh flies (Diptera: Sarcophagidae) of sandy and marshy habitats of the Polish Baltic coast. - Entomol. Fennica 20: 61-64.

The results of a seven-year study on flesh flies (Diptera: Sarcophagidae) in sandy and marshy habitats of the Polish Baltic coast are presented. During this research, carried out in 20 localities, 25 species of Sarcophagidae were collected, of which 24 were new for the study areas. Based on these results, flesh fly abundance and trophic groups are described.

E. Kaczorowska, Department of Invertebrate Zoology, University of Gdańsk, Al. Marszatka Pitsudskiego 46, 81-378 Gdynia, Poland; E-mail: saline@ocean. univ.gda.pl, telephone: 0048585236642
\end{abstract}

Received 11 December 2007, accepted 19 March 2008

\section{Introduction}

Sarcophagidae is a species-rich family, distributed worldwide and comprising over 2500 described species. At present more than 150 species of flesh flies are known from central Europe (Povolný \& Verves 1997) and 129 from Poland. The Polish fauna of Sarcophagidae is relatively well known, but the state of knowledge about these flies is uneven for particular regions of the country. The Baltic Coast, the Pomeranian Lake District, the Wielkopolsko-Kujawska and Mazovian Lowlands, the Białowieska Forest, the Lesser Poland Upland, the Bieszczady, Pieniny and Tatra Mountains are regions for which the flesh fly fauna is well studied (Draber-Mońko 1991).

Sarcophagidae perform several functions in the general ecosystem. Many species are saprophagous, coprophagous or are obligatory parasites or predators. Some are synanthropic and are potential passive vectors of pathenogenic agents, others may cause myiasis in humans and other mammals. The larvae of many Miltogramminae are inquilines in the nests of solitary, aculeate Hy- menoptera, while others are predators or parasitoids on insects and snails (Povolný \& Verves 1997). Therefore, flesh flies occur in various kinds of biotopes, including coastal marshy and sandy habitats. On the Polish Baltic coast, species of Sarcophagidae have been found in low abundance, and only one species, Sarcophaga (Myorhina) nigriventris Meigen, has so far been recorded (Draber-Mońko 1973). Szadziewski (1983), carrying out research on Diptera of the saline areas of Poland, did not collect flesh flies in general. As faunistic research on Diptera of the Baltic coast has been neglected for the last 25 years, a study of the current condition of the flesh fly fauna of these areas was considered pertinent.

\section{Material and methods}

\subsection{Study areas}

\subsubsection{Sandy habitat}

The sandy habitat was represented by 18 sampling plots, bordering the Baltic Sea, where flies 
were collected in supralittoral and epilittoral zones of beaches situated near Gdynia-Wzgórze Św. Maksymiliana, Gdynia - Redłowo, GdyniaOrłowo (UTM: CF44), Sopot, Gdańsk - Jelitkowo, Gdańsk - Brzeźno (UTM: CF43), Sobieszewo (UTM: CF62), Stegna (UTM: CF72), Krynica Morska (UTM: CF92), Jastarnia (UTM: CF46), Hel (UTM: CF55), Międzyzdroje (UTM: VV67), Ustka (UTM: XA25), Darłowo (UTM: WA83), Władysławowo (UTM: CF37), Jastrzębia Góra, Karwia (UTM: CF27) and Dębki (UTM: CF17).

\subsubsection{Marshy habitat}

The marshy habitat was represented by two localities, Gdańsk - Górki Wschodnie (UTM: CF52), situated at the mouth of the Wisła Śmiała River, and Puck (UTM: CF36). In these study localities, flies were sampled in bulrushes, brackish marshes and brackish meadows, overgrown with halophyte community which was mainly made up of Aster tripolium, Triglochin maritimum, Atriplex hastatum var. salinarium and Elymus arenarius (Szadziewski 1983).

\subsection{Flesh fly sampling}

Sarcophagid flies were collected during a sevenyear study (1999-2005) on Diptera of sandy and marshy habitats of the Polish Baltic coast, with sampling being carried out two times a month, from the beginning of April to the end of October. Flies were collected with a standard net over the water or soil, on decaying material washed ashore, and among vegetation on dunes, cliffs or saltmarshes. To be able to estimate and compare the population density of imagines, sweep samples were standardised as 400 strokes of an entomological net.

All flesh flies were mounted on pins, labelled, and deposited at the Department of Invertebrate Zoology, University of Gdańsk, Poland.

\section{Results}

The material contained 247 specimens of flesh flies, belonging to 25 species. The species are listed in Table 1 together with the absolute and relative numbers, their trophic relations and habitats.

\section{Quantitative and qualitative characteristics of the flesh fly fauna of sandy and marshy habitats of the Polish coast}

In the sandy habitat, 203 flesh fly specimens belonging to 24 species were captured. Among these, the most numerous was Sarcophaga (Sarcophaga) carnaria (Linnaeus) (29.56\% of all flesh flies collected in this study area) (Table 1). This heliophilic species, generally common and widespread in Northern Europe, prefers the vicinity of forests (Povolný \& Verves 1997), surrounding the sampling plots. In Poland, it is widely distributed and recognized as synanthropic (Draber-Mońko 1978).

A high abundance was also reached by Sarcophaga (Rosellea) aratrix Pandellé (10.34\%) and Sarcophaga (Bercaea) africa (Wiedemann) $(9.85 \%)$ (Table 1$)$. These species occur in many Polish regions. They are synanthropic (DraberMońko 1973, 1978) and culturophile. Larvae of $S$. aratrix are predators of lepidopteran pupae, whereas females of $S$. africa are attracted by many decomposing materials. It is important to emphasize that they have also been observed in maritime habitats, e.g. on carcasses. Besides, $S$. aratrix has a geopolitical distribution towards the northern limit of its range and inhabits urbanized areas (Povolný \& Verves 1997). Therefore, its abundance in study areas situated near big cities was relatively high.

In the marshy habitat, lower numbers of flesh flies were collected and only 44 specimens from 15 species were recorded. The most numerous were $S$. carnaria $(34.09 \%)$, S. africa $(18.18 \%)$, Agria affinis (Fallén) (9.09\%) and Sarcophaga (Sarcotachinella) sinuata Meigen (9.09\%) (Table 1). A. affinis prefers wet, bushy habitat, while synanthropic $S$. sinuata is found in hygrophitic plant associations near rivers, swamps and on sea shores (Povolný \& Verves 1997), and occurs on beaches along the North Sea (Karl 1930) (Table 1). Therefore, both species could find suitable ecological conditions for breeding and feeding in the marshy areas. 
Table 1. Trophic relations and abundance of the Sarcophagidae species on sandy and marshy habitats of the Polish Baltic coast.

\begin{tabular}{|c|c|c|c|c|c|c|c|}
\hline \multirow[b]{2}{*}{ Species $^{1}$} & \multirow[t]{2}{*}{$\begin{array}{l}\text { Trophic } \\
\text { relations }\end{array}$} & \multicolumn{2}{|c|}{$\begin{array}{l}\text { Sandy } \\
\text { habitat }\end{array}$} & \multicolumn{2}{|c|}{$\begin{array}{r}\text { Marshy } \\
\text { habitat }\end{array}$} & \multicolumn{2}{|c|}{ Total } \\
\hline & & No. & $\%$ & No. & $\%$ & No. & $\%$ \\
\hline Macronychia polyodon (Meig.) & In & 2 & 0.99 & 0 & 0.00 & 2 & 0.81 \\
\hline Metopia argyrocephala (Meig.) c & In & 1 & 0.49 & 0 & 0.00 & 1 & 0.40 \\
\hline Miltogramma punctata Meig. b, c, d & In & 1 & 0.49 & 1 & 2.27 & 2 & 0.81 \\
\hline Miltogramma testaceifrons (v. Ros.) d & In & 0 & 0.00 & 1 & 2.27 & 1 & 0.40 \\
\hline Oebalia cylindrica (Fall.) c & In & 1 & 0.49 & 0 & 0.00 & 1 & 0.40 \\
\hline Phrosinella nasuta (Meig.) b, c & In & 5 & 2.46 & 0 & 0.00 & 5 & 2.02 \\
\hline Senotainia conica (Fall.) b, c, d & In & 2 & 0.99 & 1 & 2.27 & 3 & 1.21 \\
\hline Taxigramma hilarella (Zett.) b, c & In & 1 & 0.49 & 0 & 0.00 & 1 & 0.40 \\
\hline Agria affinis (Fall.) & $\mathrm{Pr}$ & 9 & 4.43 & 4 & 9.09 & 13 & 5.26 \\
\hline Sarcophila latifrons (Fall.) b, c, d & $\mathrm{Pa}, \mathrm{Ne}, \mathrm{Syn}$ & 1 & 0.49 & 0 & 0.00 & 1 & 0.40 \\
\hline Blaesoxipha (Servaisia) erythrura (Meig.) b, c & $\mathrm{Pa}$ & 3 & 1.48 & 0 & 0.00 & 3 & 1.21 \\
\hline Ravinia pernix (Harr.) b, d & Co-Ne, Syn & 7 & 3.45 & 2 & 4.55 & 9 & 3.64 \\
\hline Sarcophaga (Bercaea) africa (Wied.) & Co-Ne, Syn & 20 & 9.85 & 8 & 18.18 & 28 & 11.34 \\
\hline Sarcophaga (Helicophagella) crassimargo Pand. & Co-Ne, Syn & 8 & 3.94 & 1 & 2.27 & 9 & 3.64 \\
\hline Sarcophaga (Helicophagella) melanura Meig. b, c, d & Co-Ne, Syn & 1 & 0.49 & 0 & 0.00 & 1 & 0.40 \\
\hline Sarcophaga (Heteronychia) dissimilis Meig. b & $\mathrm{Pa}$ & 3 & 1.48 & 1 & 2.27 & 4 & 1.62 \\
\hline Sarcophaga (Heteronychia) haemorrhoa Meig. b & $\mathrm{Pa}$ & 2 & 0.99 & 0 & 0.00 & 2 & 0.81 \\
\hline Sarcophaga (Heteronychia) vagans Meig. & $\mathrm{Pa}$ & 4 & 1.97 & 1 & 2.27 & 5 & 2.02 \\
\hline Sarcophaga (Myorhina) nigriventris Meig. a & $\mathrm{Pa}$ & 3 & 1.48 & 0 & 0.00 & 3 & 1.21 \\
\hline Sarcophaga (Robineauella) caerulescens Zett. d & $\mathrm{Ne}, \mathrm{Pr}$, Syn & 15 & 7.39 & 2 & 4.55 & 17 & 6.88 \\
\hline Sarcophaga (Rosellea) aratrix Pand. & Pa, Syn & 21 & 10.34 & 1 & 2.27 & 22 & 8.91 \\
\hline Sarcophaga (Sarcophaga) carnaria (L.) & $\mathrm{Pa}, \mathrm{Sa}$, Syn & 60 & 29.56 & 15 & 34.09 & 75 & 30.36 \\
\hline Sarcophaga (Sarcophaga) subvicina Rohd. & Pa, Syn & 15 & 7.39 & 1 & 2.27 & 16 & 6.48 \\
\hline Sarcophaga (Sarcotachinella) sinuata (Meig.) b & $\mathrm{Ne}, \mathrm{Pa}, \mathrm{Syn}$ & 2 & 0.99 & 4 & 9.09 & 6 & 2.43 \\
\hline Sarcophaga (Thyrsocnema) incisilobata Pand. & $\mathrm{Pr}, \mathrm{Pa}, \mathrm{Syn}$ & 16 & 7.88 & 1 & 2.27 & 17 & 6.88 \\
\hline Total & & 203 & 100 & 44 & 100 & 247 & 100 \\
\hline
\end{tabular}

1) a: species recorded on sandy beaches of the Baltic coast (Draber-Mońko 1973).

b: species recorded on the North Sea beaches by Karl 1930.

c: species recorded on the North Sea beaches by Ardö 1957

d: species recorded on the North Sea beaches by Brauns 1959.

2) In: inquilines, $\mathrm{Ne}$ : necrophages, Co: coprophages, Pr: predators, Pa: parasites or parasitoids, Sa: saprophages, Syn - synanthropic

\section{Trophic groups of the Sarcophagidae}

Flesh flies (like other Diptera) can be divided into trophic groups. The criterion to distinguish particular communities is the substrate required for the development of their larvae (Górska 1979). Based on this criterion and data from literature, groups of inquilines, parasites, predators, saprophages, necrophages and coprophages were recognized.

In the sampling plots, parasites were the most species-rich and a very abundant trophic group. They were represented by 7 species and 51 individuals on the sandy beaches, and 4 species and 4 specimens in the marshy habitat. In the study areas, the parasitic trophic group inhabits mostly sandy and dry biotopes, and larvae mainly parasitize snails or acridoid grasshoppers (Povolný \& Verves 1997). The most numerous was $S$. aratrix (Table 1). On the sampling plots, flesh flies utilising two types of substrates were also numerous. On the sandy beaches, the copro-necrophages trophic group was represented by four species and 36 individuals, and in the marshy habitat by 11 individuals belonging to three species. In each type of study area, $S$. africa was very abundant. On the sandy beaches, a high abundance was reached also by flesh flies belonging to the necrophages-predators, parasites-saprophages and 
predators-parasites trophic groups. The first one contained 15 specimens of Sarcophaga (Robineauella) caerulescens Zetterstedt. The parasites-saprophages was represented by $S$. carnaria (60 individuals) and the predators-parasites trophic group by 16 specimens of Sarcophaga (Thyrsocnema) incisilobata Pandellé (Table 1).

Thus, the high abundance of coprophagous, necrophagous and saprophagous flesh flies was strictly correlated with the habitat conditions. The beaches, where material was collected, are situated near cities known as popular resorts and places of recreation, while the marshes are adjacent to pastures with grazing cattle and rural settlements. These localities are polluted by anthropogenic and organic contaminations, which attract species developing and feeding on all types of decomposing materials.

\section{Synanthropization of the flesh fly fauna of the Polish Baltic coast}

This paper is the first study of Sarcophagidae of sandy and marshy habitats of the Polish Baltic coast, and provides analysis of the range of species and their comparative abundance in biotopes which have been partially or totally transformed by man. As the previous state of the environment is unknown, it is difficult to speculate on changes in the dipteran fauna. However, it is presumed that the synanthropic flies invaded the study areas with man.

During the research, on the beaches and in the marshy habitat, 11 synanthropic flesh fly species were collected (Table 1). The most numerous, the synanthropic fauna, was represented on sandy beaches with 166 individuals belonging to 11 species, making up $81.8 \%$ of flesh flies captured in this type of habitat. Among synanthropic Sarcophagidae, a high abundance was reached by $S$. carnaria (60 specimens), S. aratrix (21) and $S$. africa (20). In the marshy areas, 35 individuals, making up $79.5 \%$ of the sarcophagid catch and belonging to 9 species were captured, and $S$. carnaria (15 specimens) and $S$. sinuata (4) were dominant in the collection. S. carnaria, which was among the most abundant synanthropic flesh flies in each type of habitat, is recognized as ubi- quitous (Draber-Mońko 1978). This explains its relatively high abundance in study areas situated near big cities.

\section{Conclusion}

In the material collected during the research on Diptera of sandy and marshy habitats of the Polish Baltic coast, the synanthropic flesh fly species predominate. This result is correlated with the location of sampling plots near big cities (e.g. Gdańsk, Gdynia) and tourist resorts or recreation areas (e.g. Ustka, Międzyzdroje).

Moreover, the high numbers of synanthropic species and flies belonging to trophic groups with representatives feeding on various types of decomposing organic materials, indicate an increase in pollution of the environment by anthropogenic and external contaminants.

\section{References}

Ardö, P. 1957: Studies in marine shore dune ecosystem with special reference to the Dipterous fauna. Opuscula Entomologica, Supplementum 14: 9-255.

Brauns, A. 1959: Autökologische Untersuchungen über die thalassicolen Zweiflügler (Diptera) im schleswigholsteinischen Bereich der Nord- und Ostsee. - Archiv Für Hydrobiologie 55: 453-594.

Draber-Mońko, A. 1973: Review of the Sarcophagidae local species (Diptera). - Fragmenta Faunistica 19: 157-225. [In Polish]

Draber-Mońko, A. 1978: Scatophagidae, Muscinae, Gasterophilidae, Hippoboscidae, Calliphoridae, Sarcophagidae, Rhinophoridae, Oestridae, Hypodermatidae and Tachinidae (Diptera) of Pieniny. - Fragmenta Faunistica 22: 51-294. [In Polish]

Draber-Mońko, A. 1991: The Sarcophagidae flies (Diptera) of Świętokrzyskie Region. - Fragmenta Faunistica 35: 89-121. [In Polish with English abstract]

Górska, D. 1979: Communities of synanthropic flies (Diptera) in the region of Warsaw and Kalisz. - Memorabilia Zoologica 30: 3-26.

Karl, O. 1930: Thalassobionte and Thalassophile Diptera Brachycera. - In: Die Tierwelt der Nord- und Ostsee. Leipzig, XI e2: 33-84. [In German]

Povolný, D. \& Verves, Yu. G. 1997: The flesh-flies of Central Europe (Insecta, Diptera, Sarcophagidae). Spixiana, Supplement 24: 5-260.

Szadziewski, R. 1983: Flies (Diptera) of the saline habitats of Poland. - Polskie Pismo Entomologiczne 53: 31 76. 